\title{
$\alpha$-Solanine Causes Cellular Dysfunction of Human Trophoblast Cells via Apoptosis and Autophagy
}

\author{
Zhilong Chen ${ }^{1,+}$, Chen Li ${ }^{1,+}{ }^{,}$Anwen Yuan ${ }^{1}$, Ting Gu ${ }^{1}$, Feng Zhang ${ }^{1}$, Xiujun Fan ${ }^{2}$, Xiaosong Wu ${ }^{1}$, \\ Xingyao Xiong ${ }^{3, *}$ and Qing Yang ${ }^{1, *}$ \\ 1 College of Veterinary Medicine, Hunan Agricultural University, Changsha 410128, China; \\ zlongchen@stu.hunau.edu.cn (Z.C.); lichen.0904@foxmail.com (C.L.); yuananweny@hunau.edu.cn (A.Y.); \\ gut9592@stu.hunau.edu.cn (T.G.); zhangfeng0220@foxmail.com (F.Z.); wuxiaosong@hunau.edu.cn (X.W.) \\ 2 Center for Energy Metabolism and Reproduction, Institute of Biomedicine and biotechnology, Shenzhen \\ Institute of Advanced Technology, Chinese Academy of Sciences, Shenzhen 518055, China; \\ xj.fan@telomerescitech.com \\ 3 Shenzhen Agricultural Genome Research Institute, Chinese Academy of Agricultural Sciences, \\ Beijing 100081, China \\ * Correspondence: xiongxingyao@caas.cn (X.X.); qingyanghn@hunau.edu.cn (Q.Y.); \\ Tel.: +86-755-23250159 (X.X.); +86-731-84673718 (Q.Y.) \\ + These authors contributed equally to this work.
}

Citation: Chen, Z.; Li, C.; Yuan, A.; Gu, T.; Zhang, F.; Fan, X.; Wu, X.; Xiong, X.; Yang, Q. $\alpha$-Solanine Causes Cellular Dysfunction of Human Trophoblast Cells via Apoptosis and Autophagy. Toxins 2021, 13, 67. https://doi.org/ $10.3390 /$ toxins 13010067

Received: 31 October 2020 Accepted: 14 January 2021 Published: 18 January 2021

Publisher's Note: MDPI stays neutral with regard to jurisdictional claims in published maps and institutional affiliations.

Copyright: (c) 2021 by the authors. Licensee MDPI, Basel, Switzerland. This article is an open access article distributed under the terms and conditions of the Creative Commons Attribution (CC BY) license (https:// creativecommons.org/licenses/by/ $4.0 /)$.

\begin{abstract}
The trophoblast, an embryonic tissue, exerts a crucial role in the processes of implantation and placentation. Toxins in food can cause malfunction of trophoblasts, resulting in apoptosis, oxidative stress, and abnormal angiogenesis. $\alpha$-solanine, a steroidal glycoalkaloid, has antitumor properties on several cancer cells. However, its effect on human trophoblasts has not been elucidated. In this study, human extravillous trophoblast HTR-8/SVneo cells were exposed to $\alpha$-solanine. Cellular functions including proliferation, migration, invasion, tube formation, and apoptosis were assessed. To monitor autophagic flux, trophoblasts were transfected with a mCherry-GFP-LC3B vector using lentiviral transduction, and expression of autophagy-related biomarkers including Beclin 1, Atg13, and microtubule-associated protein 1 light chain-3 (MAP1-LC3) were detected. The results show that application of $20 \mu \mathrm{M} \alpha$-solanine or above inhibited the cell viability, migration, invasion, and tube formation of the human trophoblast. Cell cycle was arrested at $S$ and G2/M phases in response to $30 \mu \mathrm{M} \alpha$-solanine. $\alpha$-solanine induced apoptosis of HTR-8/SVneo cells and triggered autophagy by increasing the autophagic gene expression and stimulating the formation of autophagosome and autophagic flux. In conclusion, $\alpha$-solanine can impair the functions of human trophoblast cells via activation of cell apoptosis and autophagy.
\end{abstract}

Keywords: $\alpha$-solanine; trophoblast cell; toxicity; apoptosis; autophagy

Key Contribution: Our research found that $\alpha$-solanine exhibited cytotoxic effects on human trophoblasts with inhibition of cell proliferation, migration, invasion, and tube formation, which were mediated via activation of apoptosis and autophagy.

\section{Introduction}

Potato, rich in carbohydrates, cellulose, proteins, and minerals with low fat content, plays an indispensable role in human diet. Glycoalkaloids (GAs) generated from potatoes and all nightshade plants are natural toxins to protect plants against environmental attacks from insects, bacteria, and animals [1]. $\alpha$-solanine is one of the main GAs and abundant in potato buds and green peels. It has been revealed that $\alpha$-solanine possesses potential chemotherapeutic action against cancers in several organs, including lung [2], breast [3], esophagus [4,5], prostate [6,7], and liver [8,9], as well as acute lymphocytic leukemia [10]. $\alpha$-solanine also has potential anti-inflammatory properties [11,12]. However, potato tubers can accumulate a high concentration of GAs without proper storage, leading to toxicity 
on human health [13]. A small amount of $\alpha$-solanine can cause common symptoms such as dizziness, nausea, abdominal pain, vomiting, and diarrhea. Excessive consumption of $\alpha$-solanine can lead to convulsions, coma, and even death [14].

Animal studies have shown that $\alpha$-solanine can damage the reproductive system. It inhibits the proliferation of mouse sertoli and Leydig cells, leading to toxic effects in themale reproductive system [15]. It induces abortion in mice [16] and damages the embryo and fetus of rats and chickens $[17,18]$. Embryo development is inhibited when exposure to the steroidal GAs from potatoes in vitro [19]. It also toxically impaired the oocyte maturation, and then suppressed the embryonic development in a pig model [20]. Trophoblast, a peripheral part of blastocyst, plays important roles in implantation and placentation. During human placentation, trophoblast cells invade into the myometrium along with the uterine vasculature. Extravillous cytotrophoblast cells are highly invasive, which ensure the uterine spiral arteries remodeling. Different from tumor cells, the invasion of trophoblasts is a normal physiological behavior with moderation, which is strictly regulated by the mother [21]. With exposure to environmental changes or toxic threats, trophoblast cells become round or detached, and cell abilities such as movement, invasion, and hormone secretion may be altered [22-24]. Malfunctioning of trophoblasts leads to inflammation [25], oxidative stress [26,27], apoptosis [28,29], and dysregulated angiogenesis [30]. The toxicity of $\alpha$-solanine is well-known; however, its toxic effect on human trophoblasts is not yet understood.

In this study, we investigated the effect of $\alpha$-solanine on cell functions of human trophoblast in vitro. To determine the potential molecular mechanism of $\alpha$-solanine, we explored the changes in apoptosis, autophagic protein expression, and formation of autophagosome and autophagic flux in the trophoblast cells.

\section{Results}

\section{1. $\alpha$-Solanine Inhibited Proliferation and Induced Cell Cycle Arrest of HTR-8/SVneo Cells}

The effect of $\alpha$-solanine on proliferation of HTR-8/SVneo cells was evaluated. As shown in Figure 1, $\alpha$-solanine inhibited cell proliferation of HTR-8/SVneo when cells were treated with doses of $20 \mu \mathrm{M}$ or above (Figure 1A). Cell cycle was analyzed using flow cytometry assay. The results show that $30 \mu \mathrm{M}$ of $\alpha$-solanine treatment significantly increased the cell populations of S and G2 phases, and $20 \mu \mathrm{M} \alpha$-solanine induced S-phase cell cycle arrest (Figure 1B,C).

\section{2. $\alpha$-Solanine Induced Apoptosis in HTR-8/SVneo Cells}

To explore whether the cytotoxic effect of $\alpha$-solanine was related to cell apoptosis, HTR-8/SVneo cells were exposed with different concentrations of $\alpha$-solanine. As shown in Figure 2A,B, the percentages of apoptotic cells including the early apoptotic cells in quadrant $2(\mathrm{Q} 2)$ and late apoptotic cells in Q4 were significantly increased in response to $\alpha$-solanine at $20(11.5 \%, p<0.01)$ and $30 \mu \mathrm{M}(38.3 \%, p<0.001)$ compared to the control (6.14\%). TUNEL staining was performed to confirm the apoptotic activity of $\alpha$-solanine in HTR-8/SVneo cells, which also showed that the number of apoptotic cells increased when treated with higher concentrations (20 and $30 \mu \mathrm{M})$ of $\alpha$-solanine, while doses of $10 \mu \mathrm{M}$ or below had no significant effect on cell apoptosis (Figure 2C,D).

\section{3. $\alpha$-Solanine Inhibited Invasion and Migration of HTR-8/SVneo Cells}

Trophoblast invasive ability was determined by Matrigel transwell invasion assay. A significant decrease in the number of cells invading through transwell membrane coated with Matrigel was observed when HTR-8/SVneo cells were exposed to $20 \mu \mathrm{M} \alpha$-solanine $(p<0.001)$; few cells invaded through the membranes when exposed to $30 \mu \mathrm{M} \alpha$-solanine; and $10 \mu \mathrm{M} \alpha$-solanine showed no effect on cell invasion (Figure 3A,B). The migration assay showed similar results (Figure 3C,D). 


\section{4. $\alpha$-Solanine Inhibited the Endothelial-Like Tube Formation in HTR-8/SVneo Cells}

HTR-8/SVneo cells have an endothelial cell-like behavior to form networks [31]. We investigated the regulation of $\alpha$-solanine on the endothelial-like tube formations of HTR8/SVneo cells. Treatment with $10 \mu \mathrm{M} \alpha$-solanine showed no change in the number of nodes (Figure 4A,B), junctions (Figure $4 A, C$ ), and tubules (Figure $4 A, D$ ), as well as the total branches length (Figure 4A,E). The ability of endothelial-like tube formation decreased significantly when exposed to $20 \mu \mathrm{M} \alpha$-solanine, and no tube formation was observed when HTR-8/SVneo cells were treated with $30 \mu \mathrm{M}$ of $\alpha$-solanine.

A

B
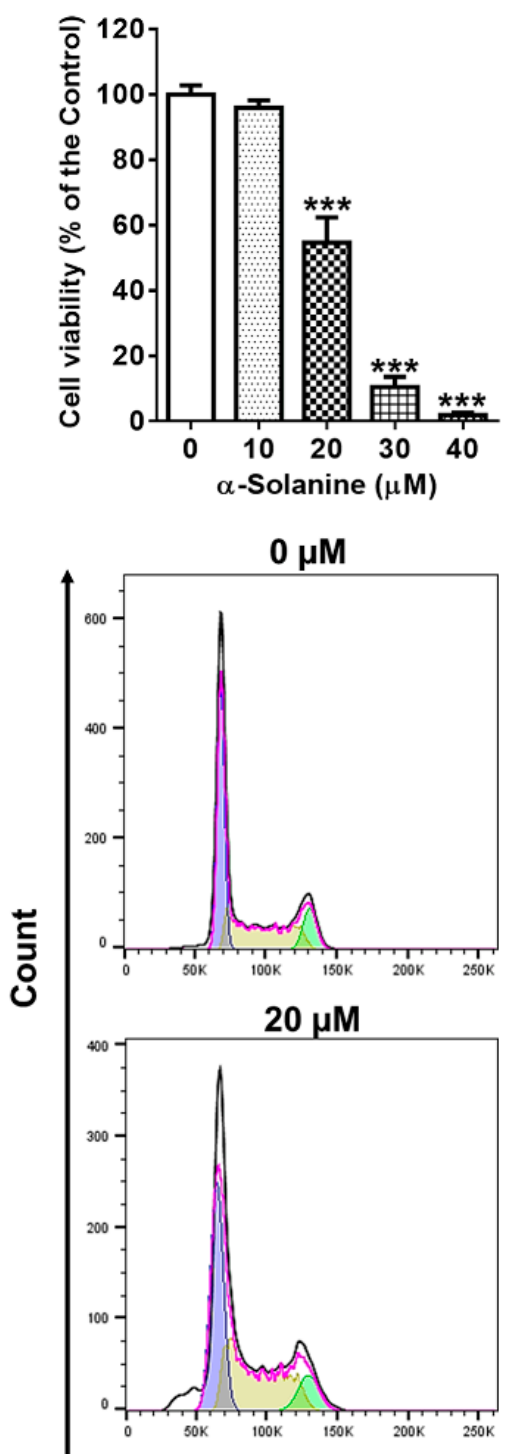

C

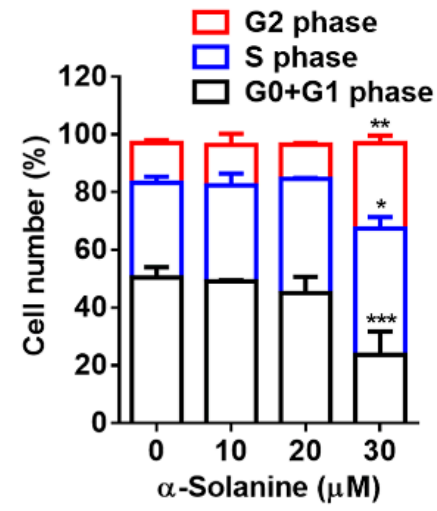

$10 \mu \mathrm{M}$

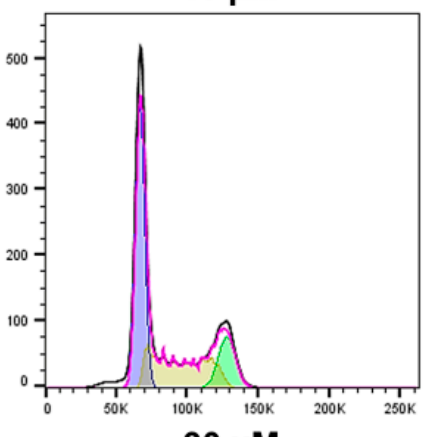

$30 \mu \mathrm{M}$

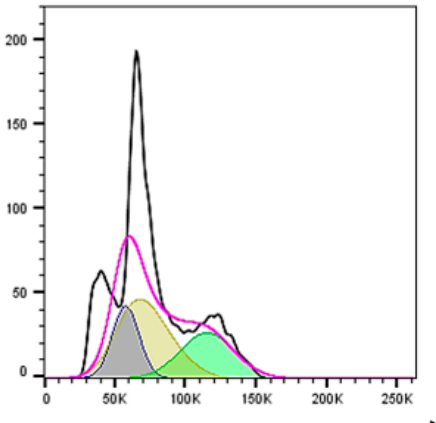

PI-A

Figure 1. $\alpha$-solanine inhibited cell proliferation and induced cell cycle arrest in HTR-8/SVneo cells (A) Cell viability was determined by CCK 8 assay after exposure to $\alpha$-solanine $(0,10,20,30$, and $40 \mu \mathrm{M})$ for $24 \mathrm{~h}$, six wells per dose. (B,C) Cell cycle distribution of HTR-8/SVneo cells treated with $\alpha$-solanine $(0,10,20$, and $30 \mu \mathrm{M})$ for $24 \mathrm{~h}$ was measured by flow cytometry analysis in triplicate. Values are the means \pm S.D. $(n=3) .{ }^{*} p<0.05,{ }^{* *} p<0.01,{ }^{* * *} p<0.001$ indicate statistically significant difference compared with the control. 
A

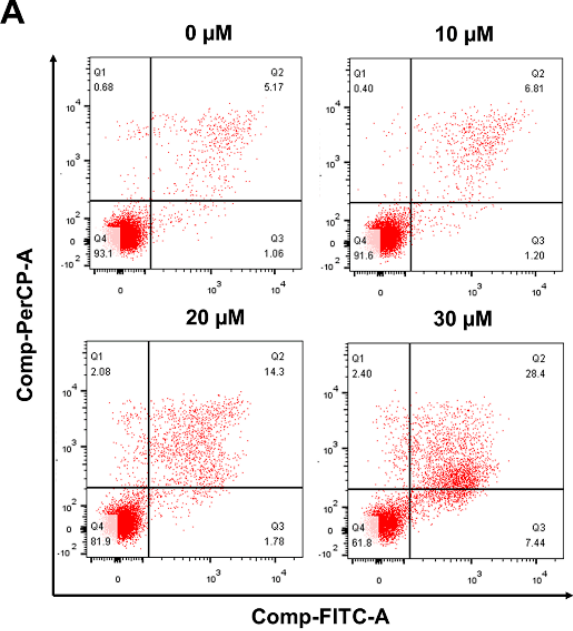

B

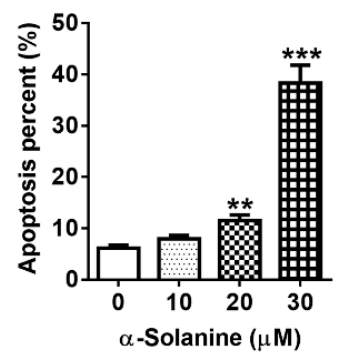

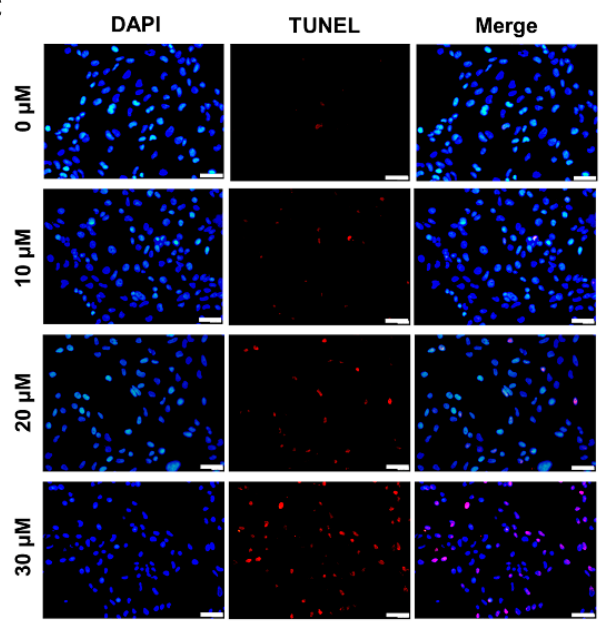

D

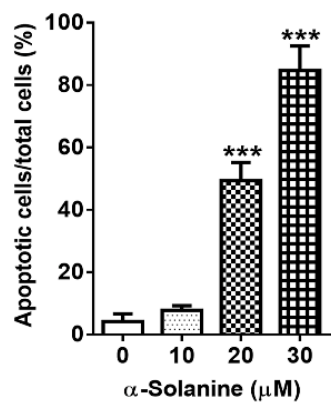

Figure 2. $\alpha$-solanine induced cell apoptosis of HTR-8/SVneo. Cells were treated with $0,10,20$, and $30 \mu \mathrm{M}$ $\alpha$-solanine for $18 \mathrm{~h}$ : (A) representative images from flow cytometry analysis with fluorescein isothiocyanate (FITC)-labeled Annexin V and propidium iodide (PI) double staining; (B) the analysis of the percentage of apoptotic cells; (C) representative images of apoptotic cells from TUNEL assay in situ (scale bar $=40$ $\mu \mathrm{m})$; and (D) quantification and analysis of the apoptotic cells. Data are presented as means \pm S.D. $(n=3)$. ${ }^{* *} p<0.01,{ }^{* * *} p<0.001$ indicate statistically significant difference compared with the control.

A
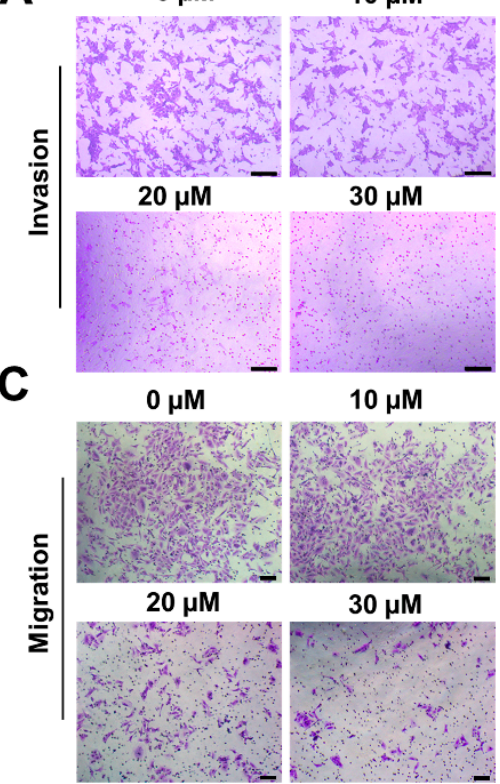

B
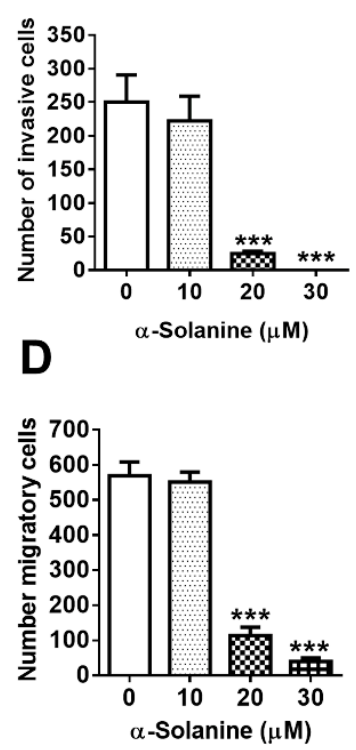

Figure 3. $\alpha$-solanine inhibited trophoblast invasion and migration. The invasion and migration of cells were measured by transwell insert with or without Matrigel-coated polycarbonate filters $(8 \mu \mathrm{m}$ pore size) in the presence of $\alpha$-solanine $(0,10,20$, and $30 \mu \mathrm{M})$ for $18 \mathrm{~h}$, respectively. (A) Representative 
images of the cells across the filters (scale bar $=100 \mu \mathrm{m}$ ). (B) The invaded cells were counted from six random fields. (C) Representative images of the cells migrating to the lower side of the filters (scale bar $=100 \mu \mathrm{m}$ ). (D) The migratory cells were counted from six random fields. Data are presented as means \pm S.D. $(n=3) .{ }^{* * *} p<0.001$ indicates significance compared with the control.

A

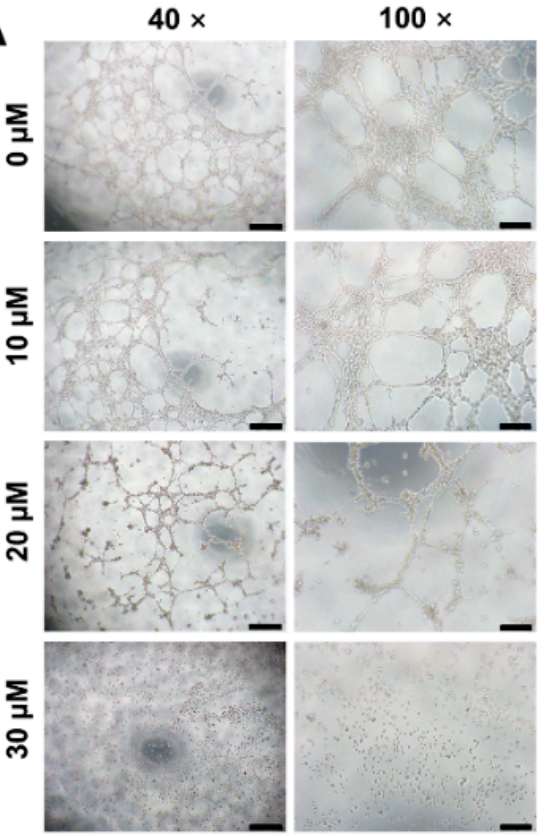

B

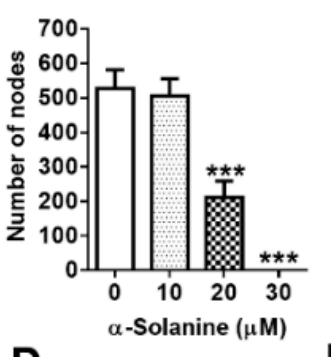

D

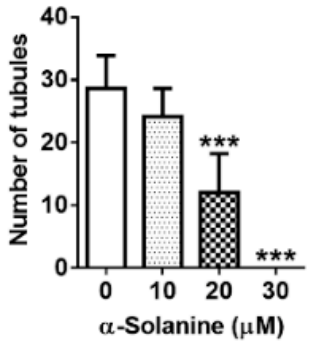

C

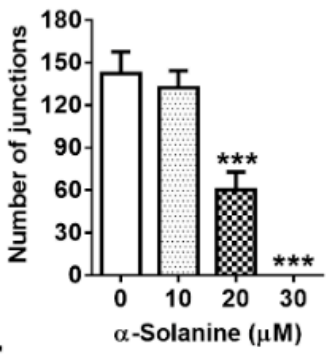

E

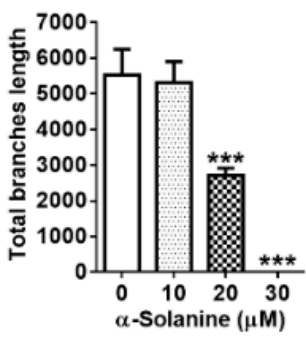

Figure 4. $\alpha$-solanine inhibited the tube formation of HTR-8/SVneo cells. Tube formation was detected after the treatment of HTR-8/SVneo cells with $\alpha$-solanine $(0,10,20$, and $30 \mu \mathrm{M})$ for $6 \mathrm{~h}$, respectively. (A) Representative images from the endothelial-like tube formation (left scale bar $=2 \mathrm{~mm}$, right scale bar $=100 \mu \mathrm{m})$. (B-E) The number of nodes, junctions, and tubules and the total branches length were quantitated from four images at $100 \times$ magnification, respectively. Data are presented as means \pm S.D. $(n=3) .{ }^{* * *} p<0.001$ indicates significance compared with the control.

\section{5. $\alpha$-Solanine Triggered Autophagy in HTR-8/SVneo Cells}

To investigate the effect of $\alpha$-solanine on autophagy of HTR-8/SVneo, cells were treated with different concentrations of $\alpha$-solanine. The results from immunoblotting show that $\alpha$-solanine increased significantly the ratio of LC3I/LC3 II, which peaked with $20 \mu \mathrm{M}$ $\alpha$-solanine treatment (Figure 5A,B,E and Figure S1). Autophagic markers, Beclin 1, and autophagy-regulated 13 (Atg13) levels was also increased when cells were exposed to $20 \mu \mathrm{M} \alpha$-solanine, but p62 expression showed no change (Figure $5 \mathrm{~A}, \mathrm{~B}, \mathrm{~F}, \mathrm{G}$ ). These results indicate that autophagy is activated in HTR-8/SVneo cells after $\alpha$-solanine treatment. To verify the activation of autophagy, trophoblast cells were co-treated with chloroquine (CQ), a common inhibitor of autophagy. The results show that co-treatment with CQ and $\alpha$-solanine increased the Beclin 1 level as well the ratio of LC3 II/I (Figure 5H,I). A tandem fluorescent LC3 (mCherry-GFP-LC3B) expression vector was used to further monitor the fusion of autophagosome and lysosome. As shown in Figure 5J, the number of green and red fluorescent puncta were increased in cells after $\alpha$-solanine treatment when compared to the controls; co-treatment with $\alpha$-solanine and CQ increased the yellow LC3 puncta. The results further confirm that $\alpha$-solanine could induce the formation of autophagosome and promote the autophagic flux in human trophoblast cells. 
A

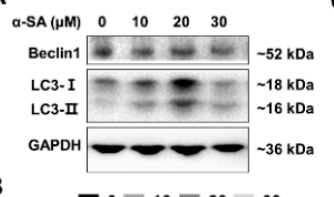

B
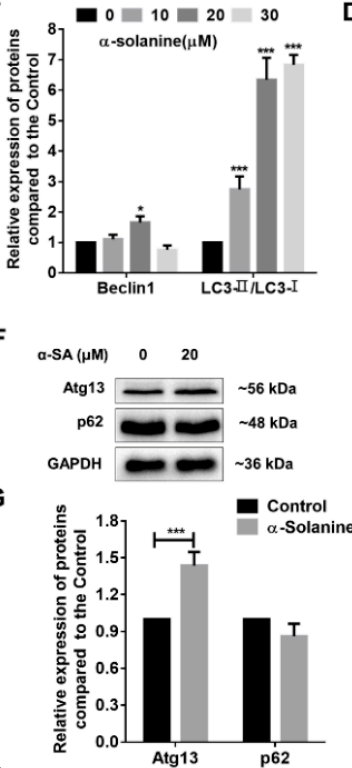

C

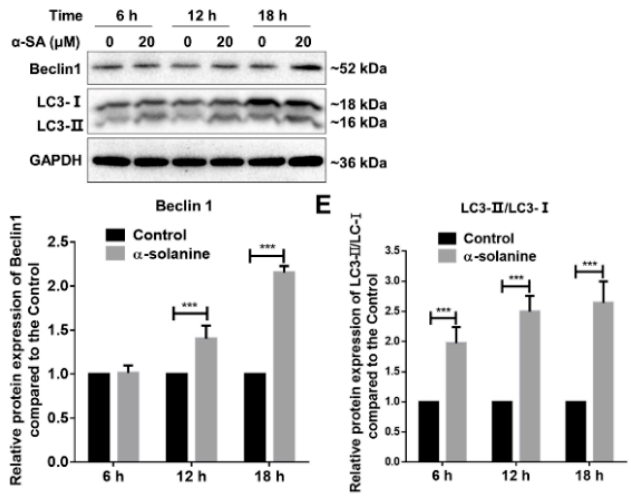

H
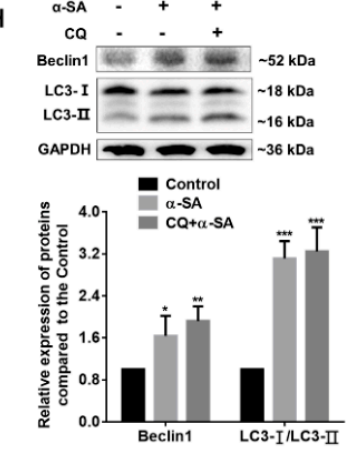

Merge

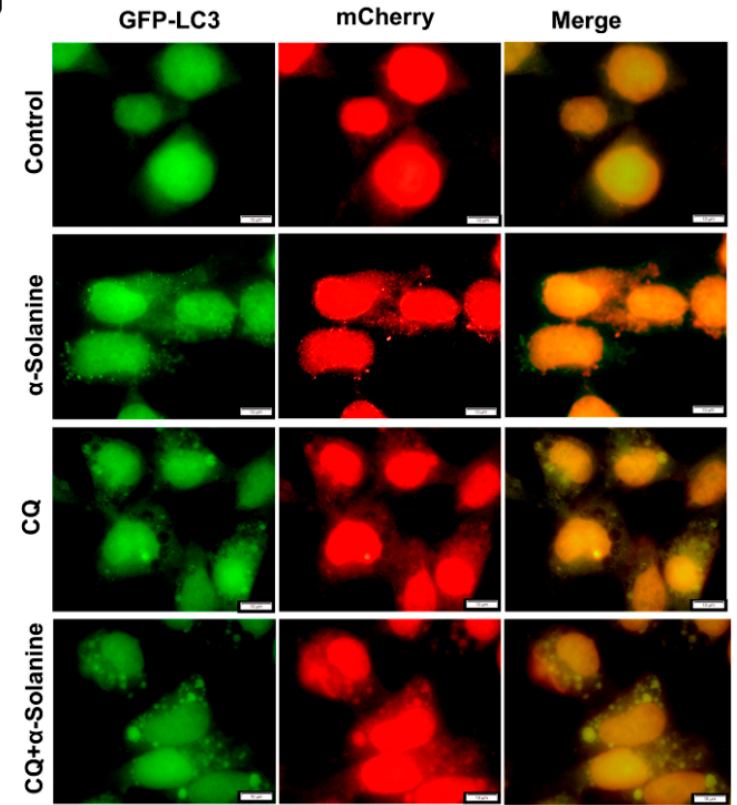

Figure 5. $\alpha$-solanine induced autophagy in HTR-8/SVneo cells. (A,B) Trophoblasts were incubated with the indicated doses of $\alpha$-solanine $(0,10,20$, and $30 \mu \mathrm{M})$ for $18 \mathrm{~h}$, and the expressions of Belclin 1 and LC3 were detected by Western blot. (C-E) Cells were exposed to $20 \mu \mathrm{M} \alpha$-solanine for 6, 12, and $18 \mathrm{~h}$, and the expressions of Belclin 1 and LC3 were analyzed. (F,G) Cells were treated with $20 \mu \mathrm{M}$ $\alpha$-solanine for $18 \mathrm{~h}$, and autophagic pathway proteins Atg13 and p62 were analyzed. $(\mathbf{H}, \mathbf{I})$ Cells were co-treated with $20 \mu \mathrm{M} \alpha$-solanine and $50 \mu \mathrm{M}$ chloroquine (CQ) for $18 \mathrm{~h}$, and the expression of Belclin 1 and LC3 were analyzed. (J) HTR-8/SVneo cells were stable transfected with lentivirus-mediated mCherry-GFP-LC3B vector and treated with $20 \mu \mathrm{M} \alpha$-solanine or co-treatment with $50 \mu \mathrm{M}$ CQ for $18 \mathrm{~h}$. The fluorescence signals were visualized and photographed under a fluorescent microscopy (scale bar $=10 \mu \mathrm{m}$ ). The yellow puncta represent autophagosome, while the red puncta represent autolysosomes. Relative intensity of the indicated protein expression was calculated by ImageJ and normalized to control. GAPDH was used as an internal control. Values are presented as means \pm S.D. $(n=3){ }^{*} p<0.05,{ }^{* *} p<0.01,{ }^{* * *} p<0.001$ indicate significant difference compared to control. 


\section{Discussion}

The present findings illustrate the $\alpha$-solanine-induced toxic effects on human trophoblast cells, which inhibited cell proliferation and induced cell cycle arrest. Moreover, $\alpha$-solanine suppressed the ability of tube formation, cell invasion, and migration when trophoblast cells were treated with $20 \mu \mathrm{M}$ or above.

HTR-8/SVneo, a human trophoblast cell line, derived from the first trimester extravillous trophoblast infected with SV40 large T antigen, is a widely used model of extravillous trophoblast [32,33]. During placentation, trophoblast cells are well-differentiated and acquire rapid proliferation and the ability to invade into the maternal endometrium to remodel utero-placental-arteries [34,35]. The tube formation is generally used for reflected placental angiogenesis and trophoblastic activity [36]. Our study demonstrated that a worse network formation was observed in $\alpha$-solanine-treated HTR-8/SVneo cells, which may impair the differentiation of the extravillous trophoblast cells into endovascular trophoblasts. Aberrant trophoblast cells disturb the placentation, which causes serious complications during pregnancy, such as preeclampsia, recurrent pregnancy loss, fetal growth restriction, and abortion [37].

A single low dose of the major compounds of GAs derived in Solanaceae, including $\alpha$-solanine, $\alpha$-chaconine, $\alpha$-tomatine, and solamargine, exerts toxic effects in many cancer cell lines [38]. The different routes of administration are closely related to GAs toxicity. The biotransformation of solamargine is quick and only a small amount of solamargine can be detected after $8 \mathrm{~h}$ of intravenous administration ( $4 \mathrm{mg} / \mathrm{kg}$ body weight) in rats [39]. solamargine is more toxic to embryos than solasonine [40]. The toxicity of $\alpha$-tomatine is lower than other GAs; more than $40 \mathrm{mg} / \mathrm{kg}$ of $\alpha$-tomatine caused the formation of abscesses via subcutaneous administration [41,42]. $\alpha$-chaconine is the most toxic of the potato Gas; the lethal dose $50 \%$ was $27.5 \mathrm{mg} / \mathrm{kg}$ body weight through intraperitoneal injection in mice [43]. $\alpha$-solanine, found at levels almost 100 -fold higher in potato sprouts than tubers, has a toxicity similar to $\alpha$-chaconine, cannot be removed through cooking, and easily accumulates in the body [44]. A combination of $\alpha$-solanine and $\alpha$-chaconine could synergistically induce the embryonic mortality and malformation in Xenopus [45]. In the present study, the cytotoxicity of high concentration of $\alpha$-solanine on human trophoblast cells may impair placentation and affect the development and growth of fetus. Animal studies need to be done to confirm the adverse effect of $\alpha$-solanine in placental development and its involvement in pregnancy outcome.

Autophagy and apoptosis are two crucial and interconnected processes during placentation, which are often influenced by microenvironmental challenges [46,47]. Autophagy is a dynamic process and highly regulated with a dual role as pro-survival or pro-death. It physiologically participates in early normal gestation, and autophagic markers were abundant in trophoblast and decidual stromal cells [48,49]. $\alpha$-solanine treatment promotes apoptosis in various cancer cells, such as liver, melanoma, and pancreatic cancer cells $[4,7,9]$. In line with these results, we also observed its apoptosis-promoting and autophagy-inducing effects in the human trophoblast cells. The ratio of LC3-II/LC3-I and the expression of Beclin 1 and Atg13 usually demonstrate the process of autophagy in cells [50,51]. In A549 cells, $\alpha$-solanine exerts its cytotoxic effect though inducing autophagy and triggering apoptosis synergistically or in parallel [52]. $\alpha$-solanine impairs the maturation of porcine oocyte by triggering autophagy as well as apoptosis, by increasing the levels of autophagy-related genes such as LC3, LAMP2, and Atg7 and enhancing the accumulation of LC3-specific puncta [20]. Consistent with the above findings, we demonstrated that, when the HTR-8/SVneo cells were exposed to $20 \mu \mathrm{M} \alpha$-solanine, Beclin 1 levels and the conversion of LC3-I to LC3-II (as ratio of LC3-II/LC3-I) peaked at $18 \mathrm{~h}$. p62, an autophagic adaptor protein that binds both LC3 and polyubiquitinated proteins for degradation on autophagosomes, is negatively correlated with autophagy activation [53]. However, in the current study, p62 was not degraded with $\alpha$-solanine-induced activation of autophagy, which may be due to the accumulation of dysfunctional proteins [54]. Autophagic inhibitor CQ can inhibit the fusion of lysosomes and autophagosome via raising the lysosomal 
$\mathrm{pH}$ [44]. Co-treatment with $\alpha$-solanine and CQ increased the Beclin 1 protein level, the ratio of LC3-II/LC3-I, and yellow LC3 puncta in the human trophoblast cells, which may result from the accumulation of autophagosome in the cytoplasm induced by $\alpha$-solanine.

\section{Conclusions}

The present findings demonstrate that $\alpha$-solanine exhibited its cytotoxic effect on human trophoblast cells. The inhibitory effect of $\alpha$-solanine may be mediated by promoting autophagy and apoptosis in HTR-8/SVneo cells. More studies are needed to disclose the involvement of $\alpha$-solanine in autophagy and apoptosis in trophoblast cells.

\section{Materials and Methods}

\subsection{Cell Culture}

The immortalized human trophoblast cell line (HTR-8/SVneo) was provided by Dr. Tsang (Department of Obstetrics \& Gynecology and Cellular \& Molecular Medicine, University of Ottawa, Ottawa, ON, Canada). Cells were cultured with Dulbecco's Modified Eagle Medium: Nutrient Mixture F12 (DMEM/F12) (Hyclone, Logan, UT, USA) containing $10 \%$ fetal bovine serum (FBS, Gibco Invitrogen Corporation, Carlsbad, CA, USA) and 1\% penicillin-streptomycin (Beyotime Biotech, Nanjing, China) and incubated in a humidified incubator (Thermo Fisher Scientific, Waltham, MA, USA) with $5 \% \mathrm{CO}_{2}$ at $37^{\circ} \mathrm{C}$.

\subsection{Cell Proliferation Assay}

Cell proliferation was assayed using CCK8 kits (Dojindo Molecular Technologies Inc., Shanghai, China). Cells were seeded in 96 -well plates with $1 \times 10^{4}$ cells per well. $\alpha$-solanine (Sigma-Aldrich, St. Louis, MO, USA), dissolved in DMSO (Sigma-Aldrich), was diluted to the indicated concentrations with the basic culture medium. As a control, solvent without $\alpha$-solanine was added to the cultures. When cells reached about $60 \%$ confluence, cells were incubated with different concentrations of $\alpha$-solanine $(0,10,20,30$, and $40 \mu \mathrm{M})$ for $24 \mathrm{~h}$, six wells per dose. After treatment, $10 \mu \mathrm{L}$ of CCK8 reagent was added and incubated for $3 \mathrm{~h}$ at $37^{\circ} \mathrm{C}$ in the dark. The absorbance at $490 \mathrm{~nm}$ was read using a microplate reader (Thermo Fisher Scientific, USA). Three independent experiments were performed, and the data were normalized to the absorbance collected from the DMSO-treated cells.

\subsection{Cell Cycle Assay}

Cell cycle assay was performed using a Cell Cycles and Apoptosis Analysis Kit (Beyotime Biotech) according to the manufacturer's instructions. Briefly, HTR-8/SVneo cells were seeded into 6-well plates, treated with $\alpha$-solanine $(0,10,20$, and $30 \mu \mathrm{M})$ for $24 \mathrm{~h}$. Cells were harvested and fixed in $70 \%$ ethanol overnight at $4{ }^{\circ} \mathrm{C}$, and subsequently washed with phosphate buffered saline (PBS). PI solution containing $50 \mu \mathrm{g} / \mathrm{mL}$ RNase was then added to the cells and incubated at $37^{\circ} \mathrm{C}$ for $30 \mathrm{~min}$ in the dark. Cell cycle analysis was performed on a Becton-Dickinson (BD) FACS system (Becton-Dickinson, San-Jose, CA, USA).

\subsection{Cell Invasion and Migration Assays}

Matrigel invasion and migration of HTR-8/SVneo cells were performed as described previously with modification [55]. Briefly, $5 \times 10^{5} \mathrm{HTR}-8 / \mathrm{SV}$ neo cells in $200 \mu \mathrm{L}$ serum-free medium with or without $\alpha$-solanine $(0,10,20$, and $30 \mu \mathrm{M})$ were seeded into the chamber of the transwell insert (pore size $8.0 \mu \mathrm{m}$, Corning Life Sciences, Acton, MA, USA), which was pre-coated with Matrigel (Becton Dickinson Biosciences, Franklin Lakes, NJ, USA). Medium containing 10\% FBS was added to the 24-well plate. After culturing for $18 \mathrm{~h}$, non-invaded cells were scraped off the upper surface of the insert with cotton swabs. The cells invading through the surface were fixed with $4 \%$ paraformaldehyde (PFA) for $20 \mathrm{~min}$, and then stained with a $0.1 \%$ crystal violet solution for $30 \mathrm{~min}$. Images of invaded cells from six random fields were photographed under a microscope (Olympus, IX73P1F, Tokyo, Japan) and counted using ImageJ software. Cell migration was detected using the 
procedures similar to those in cell invasion assay, except the upper chamber was not coated with Matrigel.

\subsection{Tube Formation Assay}

Networks formed in trophoblasts was evaluated utilizing tube formation assay as described previously with slight modifications [56]. Ninety-six-well plates were coated with Matrigel (50 $\mu \mathrm{L}$ per well) and solidified at $37^{\circ} \mathrm{C}$ for $1 \mathrm{~h}$. HTR-8/SVneo cells were suspended in serum-free DMEM/F12 medium containing different doses of $\alpha$-solanine $(0,10,20$, and $30 \mu \mathrm{M})$ and seeded on the Matrigel at a density of $1 \times 10^{5}$ cells per well. After incubating for $6 \mathrm{~h}$, tube-like structures were observed under a microscope (Olympus, IX73P1F, Japan). The number of nodes, junctions, and tubules and the total branches length from five random fields were quantified by ImageJ software.

\subsection{Cell Apoptosis Assay}

An Annexin V-FITC/PI Apoptosis Detection kit (Thermo Fisher Scientific, USA) was used to stain apoptosis cells according the manufacturer's instructions. After HTR-8/SVneo cells were treated with different concentrations of $\alpha$-solanine $(0,10,20$, and $30 \mu \mathrm{M})$ for $18 \mathrm{~h}$, cells were collected and washed once with cold PBS. Cells were resuspended with $100 \mu \mathrm{L}$ of $1 \times$ binding buffer followed by staining with Annexin V-FITC and PI solution. Then, $200 \mu \mathrm{L}$ binding buffer was added. Cells were analyzed by flow cytometry using the software FlowJo-V10 (Tree Star, Ashland, OR, USA).

\subsection{TUNEL Assay}

TUNEL assay was performed using a DNA Fragmentation Detection Kit (Beyotime Biotech), as described previously [57]. Briefly, cells were treated with $\alpha$-solanine for $18 \mathrm{~h}$, fixed with $4 \%$ PFA for $30 \mathrm{~min}$, rinsed with PBS, and permeabilized with Triton X-100 $(0.1 \%)$ on ice. Then, cells were stained with TUNEL staining mixture for $1 \mathrm{~h}$ at $37^{\circ} \mathrm{C}$ in the dark and counterstained with $4^{\prime}, 6^{\prime}$ diamidino-2-phenylindole (DAPI) for $5 \mathrm{~min}$ at room temperature. The apoptotic cells were observed using a fluorescence microscope (Olympus, IX73P1F, Japan). Cells from five random fields were counted using ImageJ software.

\subsection{Western Blot}

After treatment, cells were lysed in RIPA buffer (Beyotime) containing phenylmethylsulfonyl fluoride (1 mM, Sigma-Aldrich) for $30 \mathrm{~min}$ followed by centrifuge. Equal amounts of protein were separated by SDS-PAGE and transferred onto polyvinylidene difluoride (PVDF) membranes (Millipore Inc., USA). Membranes were blocked with $0.2 \%$ gelatin, then incubated with the indicated primary antibodies to Beclin 1 (ab62557, Abcam, Cambridge, UK), LC3 (ab51520, Abcam), Atg13 (GB11591, Servicebio, Wuhan, China), SQSTM1/p62 (GB11531, Servicebio) and GAPDH (KC-5G5, Kangcheng Bio-tech, Sichuan, China) at $4{ }^{\circ} \mathrm{C}$ overnight. After washing in TBST, the membranes were incubated with the corresponding horseradish peroxidase (HRP)-linked antibodies. The blots were developed using an enhanced chemiluminescence (ECL)-plus kit (Beyotime, China) and visualized by the ChemiDoc XRS+ system (Bio-Rad, Hercules, CA, USA).

\subsection{Autophagic Flux}

To monitor autophagic flux inducing by $\alpha$-solanine, trophoblasts were transfected with a mCherry-GFP-LC3B vector (MiaoLingBio, Wuhan, China) via lentiviral transduction. After co-treatment with $20 \mu \mathrm{M} \alpha$-solanine and $50 \mu \mathrm{M}$ CQ or without for $18 \mathrm{~h}$, cells were fixed with $4 \%$ PFA, and DAPI was used to dye nucleus. The fluorescence signals were checked using a fluorescence microscope (Olympus, BX53F, Japan). 


\subsection{Statistical Analysis}

Results are presented as mean \pm standard error (S.D.) from three independent experiments. Student's T test or One-Way ANOVA test was used for statistical analysis. ${ }^{*} p<0.05$, ${ }^{* *} p<0.01$, and ${ }^{* * *} p<0.001$ were considered for statistical significance.

Supplementary Materials: The following are available online at https://www.mdpi.com/2072-6 $651 / 13 / 1 / 67 /$ s1, Figure S1: $\alpha$-solanine induced the expression of autophagy-related biomarkers of HTR-8/SVneo cells.

Author Contributions: Conceptualization, Q.Y. and X.X.; methodology, Z.C., C.L., T.G., and F.Z.; software, Z.C.; validation, A.Y., X.F., and X.W.; original draft preparation, Z.C. and C.L.; writing-review and editing, Z.C., C.L., A.Y., F.Z., X.F., X.W., Q.Y., and X.X.; supervision, Q.Y.; and project administration, Q.Y., X.W., and X.F. All authors have read and agreed to the published version of the manuscript.

Funding: This work was supported by grants from National Natural Sciences Foundation of China (Nos. 31572591, 31772819, and 81830041) and the National Key Research and Development Program of China (2018YFD0200800).

Institutional Review Board Statement: Not applicable.

Informed Consent Statement: Not applicable.

Data Availability Statement: Data are available upon request, please contact the contributing authors.

Conflicts of Interest: The authors declare no conflict of interest.

\section{References}

1. Friedman, M. Potato glycoalkaloids and metabolites: Roles in the plant and in the diet. J. Agric. Food Chem. 2006, 54, 8655-8681. [CrossRef] [PubMed]

2. Zhang, F.; Yang, R.; Zhang, G.; Cheng, R.; Bai, Y.; Zhao, H.; Lu, X.; Li, H.; Chen, S.; Li, J.; et al. Anticancer function of $\alpha$-solanine in lung adenocarcinoma cells by inducing microRNA-138 expression. Tumor Biol. 2016, 37, 6437-6446. [CrossRef] [PubMed]

3. Mohsenikia, M.; Farhangi, B.; Alizadeh, A.M.; Khodayari, H.; Khodayari, S.; Khori, V.; Arjmand Abbassi, Y.; Vesovic, M.; Soleymani, A.; Najafi, F. Therapeutic effects of dendrosomal solanine on a metastatic breast tumor. Life Sci. 2016, 148, 260-267. [CrossRef] [PubMed]

4. Wu, J.; Wang, L.; Du, X.; Sun, Q.; Wang, Y.; Li, M.; Zang, W.; Liu, K.; Zhao, G. $\alpha$-solanine enhances the chemosensitivity of esophageal cancer cells by inducing microRNA-138 expression. Oncol. Rep. 2018, 39, 1163-1172. [CrossRef] [PubMed]

5. Wang, L.; Sun, Q.Q.; Zhang, S.J.; Du, Y.W.; Wang, Y.Y.; Zang, W.Q.; Chen, X.N.; Zhao, G.Q. Inhibitory effect of $\alpha$-solanine on esophageal carcinoma in vitro. Exp. Ther. Med. 2016, 12, 1525-1530. [CrossRef] [PubMed]

6. Lv, C.; Kong, H.; Dong, G.; Liu, L.; Tong, K.; Sun, H.; Chen, B.; Zhang, C.; Zhou, M. Antitumor efficacy of $\alpha$-solanine against pancreatic cancer in vitro and in vivo. PLoS ONE 2014, 9, e87868. [CrossRef]

7. Shen, K.H.; Liao, A.C.; Hung, J.H.; Lee, W.J.; Hu, K.C.; Lin, P.T.; Liao, R.F.; Chen, P.S. $\alpha$-Solanine inhibits invasion of human prostate cancer cell by suppressing epithelial-mesenchymal transition and MMPs expression. Molecules 2014, 19, 11896-11914. [CrossRef]

8. Meng, X.Q.; Zha, W.; Zhang, F.; Yin, S.Y.; Xie, H.Y.; Zhou, L.; Zheng, S.S. Solanine-induced reactive oxygen species inhibit the growth of human hepatocellular carcinoma HepG2 cells. Oncol. Lett. 2016, 11, 2145-2151. [CrossRef]

9. El-Daly, S.M.; Gouhar, S.A.; Gamal-Eldeen, A.M.; Abdel Hamid, F.F.; Ashour, M.N.; Hassan, N.S. Synergistic effect of $\alpha$-Solanine and Cisplatin induces apoptosis and enhances cell cycle arrest in human hepatocellular carcinoma cells. Anticancer Agents Med. Chem. 2019, 19, 2197-2210. [CrossRef]

10. Yi, Y.J.; Jia, X.H.; Wang, J.Y.; Chen, J.R.; Wang, H.; Li, Y.J. Solanine induced apoptosis and increased chemosensitivity to Adriamycin in T-cell acute lymphoblastic leukemia cells. Oncol. Lett. 2018, 15, 7383-7388. [CrossRef]

11. Shin, J.S.; Lee, K.G.; Lee, H.H.; Lee, H.J.; An, H.J.; Nam, J.H.; Jang, D.S.; Lee, K.T. $\alpha$-Solanine isolated from Solanum Tuberosum L. cv Jayoung abrogates LPS-induced inflammatory responses via NF- $k B$ inactivation in RAW 264.7 macrophages and endotoxininduced shock model in mice. J. Cell Biochem. 2016, 117, 2327-2339. [CrossRef] [PubMed]

12. Zhao, L.; Wang, L.; Di, S.N.; Xu, Q.; Ren, Q.C.; Chen, S.Z.; Huang, N.; Jia, D.; Shen, X.F. Steroidal alkaloid solanine A from Solanum Nigrum Linn. exhibits anti-inflammatory activity in lipopolysaccharide/interferon $\gamma$-activated murine macrophages and animal models of inflammation. Biomed. Pharmacother. 2018, 105, 606-615. [CrossRef]

13. Friedman, M.; Mcdonald, G.M. Potato glycoalkaloids: Chemistry, analysis, safety, and plant physiology. Crit. Rev. Plant Sci. 1997, 16, 55-132. [CrossRef] 
14. Langkilde, S.; Schrøder, M.; Stewart, D.; Meyer, O.; Conner, S.; Davies, H.; Poulsen, M. Acute toxicity of high doses of the glycoalkaloids, alpha-solanine and alpha-chaconine, in the Syrian Golden hamster. J. Agric. Food Chem. 2008, 56, 8753-8760. [CrossRef] [PubMed]

15. Park, S.; Park, M.Y.; Song, G.; Lim, W. Alpha-solanine inhibits cell proliferation via mitochondrial dysfunction and inhibin synthesis in mouse testis in vitro and in vivo. Chemosphere 2019, 235, 271-279. [CrossRef]

16. Friedman, M.; Henika, P.R.; Mackey, B.E. Effect of feeding solanidine, solasodine and tomatidine to non-pregnant and pregnant mice. Food Chem. Toxicol. 2003, 41, 61-71. [CrossRef]

17. Hellenäs, K.E.; Cekan, E.; Slanina, P.; Bergman, K. Studies of embryotoxicity and the incidence of external malformations after continuous intravenous infusion of alpha-chaconine in pregnant rats. Pharmacol. Toxicol. 1992, 70, 381-383. [CrossRef]

18. Jelínek, R.; Kyzlink, V.; Blatiný, C., Jr. An evaluation of the embryotoxic effects of blighted potatoes on chicken embryos. Teratology 1976, 14, 335-342. [CrossRef]

19. Wang, S.; Panter, K.E.; Gaffield, W.; Evans, R.C.; Bunch, T.D. Effects of steroidal glycoalkaloids from potatoes (Solanum tuberosum) on in vitro bovine embryo development. Anim. Reprod. Sci. 2005, 85, 243-250. [CrossRef]

20. Lin, T.; Oqani, R.K.; Lee, J.E.; Kang, J.W.; Kim, S.Y.; Cho, E.S.; Jeong, Y.D.; Baek, J.J.; Jin, D.I. $\alpha$-Solanine impairs oocyte maturation and quality by inducing autophagy and apoptosis and changing histone modifications in a pig model. Reprod. Toxicol. 2018, 75, 96-109. [CrossRef]

21. Ji, L.; Brkić, J.; Liu, M.; Fu, G.; Peng, C.; Wang, Y.L. Placental trophoblast cell differentiation: Physiological regulation and pathological relevance to preeclampsia. Mol. Aspects Med. 2013, 34, 981-1023. [CrossRef] [PubMed]

22. Correia-Branco, A.; Keating, E.; Martel, F. Placentation-related processes in a human first-trimester extravillous trophoblast cell line (HTR-8/SVneo cells) are affected by several xenobiotics. Drug Chem. Toxicol. 2019, 42, 541-545. [CrossRef] [PubMed]

23. Komine-Aizawa, S.; Hirohata, N.; Aizawa, S.; Abiko, Y.; Hayakawa, S. Porphyromonas gingivalis lipopolysaccharide inhibits trophoblast invasion in the presence of nicotine. Placenta 2015, 36, 27-33. [CrossRef] [PubMed]

24. Scalise, M.L.; Amaral, M.M.; Reppetti, J.; Damiano, A.E.; Ibarra, C.; Sacerdoti, F. Cytotoxic effects of Shiga toxin-2 on human extravillous trophoblast cell lines. Reproduction 2019, 157, 297-304. [CrossRef]

25. Negi, M.; Mulla, M.J.; Han, C.S.; Abrahams, V.M. Allopurinol inhibits excess glucose-induced trophoblast IL-1 $\beta$ and ROS production. Reproduction 2020, 159, 73-80. [CrossRef]

26. Cindrova-Davies, T.; Spasic-Boskovic, O.; Jauniaux, E.; Charnock-Jones, D.S.; Burton, G.J. Nuclear factor-kappa B, p38, and stress-activated protein kinase mitogen-activated protein kinase signaling pathways regulate proinflammatory cytokines and apoptosis in human placental explants in response to oxidative stress: Effects of antioxidant vitamins. Am. J. Pathol. 2007, 170, 1511-1520.

27. Burdon, C.; Mann, C.; Cindrova-Davies, T.; Ferguson-Smith, A.C.; Burton, G.J. Oxidative stress and the induction of cyclooxygenase enzymes and apoptosis in the murine placenta. Placenta 2007, 28, 724-733. [CrossRef]

28. Huppertz, B.; Kadyrov, M.; Kingdom, J.C. Apoptosis and its role in the trophoblast. Am. J. Obstet. Gynecol. 2006, 195, 29-39. [CrossRef]

29. Tomas, S.Z.; Prusac, I.K.; Roje, D.; Tadin, I. Trophoblast apoptosis in placentas from pregnancies complicated by preeclampsia. Gynecol. Obstet. Investig. 2011, 71, 250-255. [CrossRef]

30. Maynard, S.E.; Karumanchi, S.A. Angiogenic factors and preeclampsia. Semin. Nephrol. 2011, 31, 33-46. [CrossRef]

31. Dokras, A.; Gardner, L.M.; Seftor, E.A.; Hendrix, M.J. Regulation of human cytotrophoblast morphogenesis by hepatocyte growth factor/scatter factor. Biol. Reprod. 2001, 65, 1278-1288. [CrossRef] [PubMed]

32. Graham, C.H.; Hawley, T.S.; Hawley, R.G.; MacDougall, J.R.; Kerbel, R.S.; Khoo, N.; Lala, P.K. Establishment and characterization of first trimester human trophoblast cells with extended lifespan. Exp. Cell Res. 1993, 206, 204-211. [CrossRef] [PubMed]

33. Chang, W.; Yang, Q.; Zhang, H.; Lin, H.; Zhou, Z.; Lu, X.; Zhu, C.; Xue, L.Q.; Wang, H. Placenta specific protein 1 (PLAC1) is involved in the trophoblasts invasion and migration. Reproduction 2014, 148, 343-352. [CrossRef] [PubMed]

34. Burton, G.J.; Woods, A.W.; Jauniaux, E.; Kingdom, J.C. Rheological and physiological consequences of conversion of the maternal spiral arteries for uteroplacental blood flow during human pregnancy. Placenta 2009, 30, 473-482. [CrossRef]

35. Carter, A.M.; Enders, A.C.; Pijnenborg, R. The role of invasive trophoblast in implantation and placentation of primates. Philos. Trans. R. Soc. Lond. B Biol. Sci. 2015, 370, 20140070. [CrossRef]

36. Basak, S.; Duttaroy, A.K. Leptin induces tube formation in first-trimester extravillous trophoblast cells. Eur. J. Obstet. Gynecol. Reprod. Biol. 2012, 164, 24-29. [CrossRef]

37. Lyall, F.; Robson, S.C.; Bulmer, J.N. Spiral artery remodeling and trophoblast invasion in preeclampsia and fetal growth restriction: Relationship to clinical outcome. Hypertension 2013, 62, 1046-1054. [CrossRef]

38. Sucha, L.; Tomsik, P. The Steroidal Glycoalkaloids from Solanaceae: Toxic Effect, Antitumour Activity and Mechanism of Action. Planta Med. 2016, 82, 379-387. [CrossRef]

39. Zheng, X.; Xu, L.; Liang, Y.; Xiao, W.; Xie, L.; Zhang, Y.; Zhao, L.; Cao, L.; Chen, J.; Wang, G. Quantitative determination and pharmacokinetic study of solamargine in rat plasma by liquid chromatogramy-mass spectrometry. J. Pharm. Biomed. Anal. 2011, 55, 1157-1162. [CrossRef]

40. Blankemeyer, J.T.; McWilliams, M.L.; Rayburn, J.R.; Weissenberg, M.; Friedman, M. Developmental toxicology of solamargine and solasonine glycoalkaloids in frog embryos. Food Chem. Toxicol. 1998, 36, 383-389. [CrossRef] 
41. Friedman, M.; Fitch, T.E.; Yokoyama, W.E. Lowering of plasma LDL cholesterol in hamsters by the tomato glycoalkaloid tomatine. Food Chem. Toxicol. 2000, 38, 549-553. [CrossRef]

42. Roddick, J.G. The steroidal glycoalkaloid $\alpha$-tomatine. Phytochemistry 1974, 13, 9-25. [CrossRef]

43. Nishie, K.; Norred, W.P.; Swain, A.P. Pharmacology and toxicology of chaconine and tomatine. Res. Commun. Chem. Pathol. Pharmacol. $1975,12,657-668$.

44. Mensinga, T.T.; Sips, A.J.; Rompelberg, C.J.; van Twillert, K.; Meulenbelt, J.; van den Top, H.J.; van Egmond, H.P. Potato glycoalkaloids and adverse effects in humans: An ascending dose study. Regul. Toxicol. Pharmacol. 2005, 41, 66-72. [CrossRef]

45. Rayburn, J.R.; Friedman, M.; Bantle, J.A. Synergistic interaction of glycoalkaloids $\alpha$-chaconine and $\alpha$-solanine on developmental toxicity in Xenopus embryos. Food Chem. Toxicol. 1995, 33, 1013-1019. [CrossRef]

46. Levy, R.; Nelson, D.M. To be, or not to be, that is the question. Apoptosis in human trophoblast. Placenta 2000, 21, 1-13. [CrossRef] [PubMed]

47. Erboga, M.; Kanter, M. Effect of cadmium on trophoblast cell proliferation and apoptosis in different gestation periods of rat placenta. Biol. Trace Elem. Res. 2006, 169, 285-293. [CrossRef] [PubMed]

48. Avagliano, L.; Terraneo, L.; Virgili, E.; Martinelli, C.; Doi, P.; Samaja, M.; Bulfamante, G.P.; Marconi, A.M. Autophagy in normal and abnormal early human pregnancies. Reprod. Sci. 2015, 22, 838-844. [CrossRef]

49. Gao, L.; Qi, H.B.; Kamana, K.C.; Zhang, X.M.; Zhang, H.; Baker, P.N. Excessive autophagy induces the failure of trophoblast invasion and vasculature: Possible relevance to the pathogenesis of preeclampsia. J. Hypertens. 2015, 33, 106-117. [CrossRef]

50. Hseu, Y.C.; Shen, Y.C.; Kao, M.C.; Mathew, D.C.; Karuppaiya, P.; Li, M.L.; Yang, H.L. Ganoderma tsugae induced ROSindependent apoptosis and cytoprotective autophagy in human chronic myeloid leukemia cells. Food Chem. Toxicol. 2019, 124, 30-44. [CrossRef]

51. Klionsky, D.J.; Baehrecke, E.H.; Brumell, J.H.; Chu, C.T.; Codogno, P.; Cuervo, A.M.; Debnath, J.; Deretic, V.; Elazar, Z.; Eskelinen, E.L.; et al. A comprehensive glossary of autophagy-related molecules and processes (2nd edition). Autophagy 2011, 7, 1273-1294. [CrossRef] [PubMed]

52. Hasanain, M.; Bhattacharjee, A.; Pandey, P.; Ashraf, R.; Singh, N.; Sharma, S.; Vishwakarma, A.L.; Datta, D.; Mitra, K.; Sarkar, J. alpha-Solanine induces ROS-mediated autophagy through activation of endoplasmic reticulum stress and inhibition of Akt/mTOR pathway. Cell Death Dis. 2015, 6, e1860. [CrossRef] [PubMed]

53. Donohue, E.; Balgi, A.D.; Komatsu, M.; Roberge, M. Induction of Covalently Crosslinked p62 Oligomers with Reduced Binding to Polyubiquitinated Proteins by the Autophagy Inhibitor Verteporfin. PLoS ONE 2014, 9, e114964. [CrossRef] [PubMed]

54. B'chir, W.; Maurin, A.C.; Carraro, V.; Averous, J.; Jousse, C.; Muranishi, Y.; Parry, L.; Stepien, G.; Fafournoux, P.; Bruhat, A. The eIF2 $\alpha$ /ATF4 pathway is essential for stress-induced autophagy gene expression. Nucleic Acids Res. 2013, 41, 7683-7699. [CrossRef] [PubMed]

55. Yang, Q.; Chen, S.P.; Zhang, X.P.; Wang, H.; Zhu, C.; Lin, H.Y. Smurf2 participates in human trophoblast cell invasion by inhibiting TGF-beta type I receptor. J. Histochem. Cytochem. 2009, 57, 605-612. [CrossRef]

56. Zhang, J.; Peng, X.; Yuan, A.; Xie, Y.; Yang, Q.; Xue, L. Peroxisome proliferator-activated receptor $\gamma$ mediates porcine placental angiogenesis through hypoxia inducible factor-, vascular endothelial growth factor- and angiopoietin-mediated signaling. Mol. Med. Rep. 2017, 16, 2636-2644. [CrossRef]

57. Chen, Z.; Zhang, J.; Yuan, A.; Han, J.; Tan, L.; Zhou, Z.; Zhao, H.; Su, R.; Huang, B.; Wang, B.; et al. R-spondin3 promotes the tumor growth of choriocarcinoma JEG-3 cells. Am. J. Physiol. Cell Physiol. 2020, 318, C664-C674. [CrossRef] 